\title{
EPGN Gene
}

National Cancer Institute

\section{Source}

National Cancer Institute. EPGN Gene. NCI Thesaurus. Code C105918.

This gene plays a role in epithelial cell growth. 